\title{
Silent shields: international humanitarian law at the limits of audibility
}

\section{Thomas Gregory ${ }^{1}$}

Accepted: 15 December 2021 / Published online: 8 February 2022

(c) The Author(s) 2022

\begin{abstract}
In my contribution to this forum, I want to focus on the silencing of human shields within the prevailing frames of war/law. Focusing on the destruction of al-Jalaa tower by the Israeli Defence Forces (IDF), I argue that Human Shields: A History of People in the Line of Fire enables us to see how the figure of the human shield was invoked to legitimize this violence whilst denying the victims a voice within debates about the harm inflicted upon them. Although the book enables us to trace how the discourse on human shielding works to dehumanize and depoliticize the victims, I encourage the authors to think about the silences and omissions in their own work and to think about what could be done to contest these silences. I draw on the work of Gayatri Spivak, Jacques Rancière, and Banu Bargu to illustrate my concerns about the problem and potential solutions to this problem.
\end{abstract}

Keywords Human Shields · International Humanitarian Law · Civilian Casualties · Silence $\cdot$ Agency

\section{Introduction}

I finished re-reading Human Shields: A History of People in the Line of Fire the day before the Israeli Defence Forces (IDF) bombed al-Jalaa tower, an 11-storey apartment building in central Gaza that housed several media outlets. The importance of the book was immediately and terrifyingly apparent. The IDF claimed that the attack was lawful because the building "contained military assets belonging to the intelligence offices of the Hamas terror organisation" (IDF, 2021a). The IDF argued that Hamas was responsible for the damage to civilian property because it "chooses to hide among civilians" (IDF, 2021b). In a subsequent statement, the IDF argued that the apartment building had been "vetted" in accordance with IDF procedures, that "significant efforts" were made so that civilians could evacuate the building, and

Thomas Gregory

t.gregory@auckland.ac.nz

1 Auckland University, Auckland, New Zealand 
that "the evacuation process was meticulous [so...] no civilians were harmed" (IDF, 2021c). As Neve Gordon and Nicola Perugini argue, statements like these reinforce the illusion that lethal force can be carefully calibrated to ensure that the military can continue to kill those who need to be killed without causing unnecessary harm to civilians (2020, pp. 176-177). When civilians die or their homes are decimated, Gordon and Perugini show how statements like these enable the perpetrator to disavow responsibility for any death and destruction, locating it instead with the militants accused of hiding behind human shields or the civilians who failed to evacuate the blast area (2020, pp. 176-177).

Human Shields became an invaluable companion in the weeks that followed the attack on al-Jalaa, outlining the conceptual tools needed to navigate the legal arguments that ensued. The book does so many important things. It traces the origin and evolution of the term, explaining the distinction that is often drawn between voluntary and involuntary shields (2020, p. 6). It documents specific historical examples where civilians have volunteered to serve as shields, where civilians have been forced to serve as shields, and examples where civilians have been classified as human shields without them knowing. Gordon and Perugini also explain how the figure of the human shield has been weaponized in debates about contemporary practices of violence with belligerents invoking it to "legitimize the use of lethal force against innocent people" (2020, p. 10). What really interested me, however, was how the discourse on human shielding works to dehumanize those classified as human shields, transforming these individuals into eminently killable subjects. Even though the term seems to reaffirm the humanity of those serving as human shields, Gordon and Perugini outline how 'the story of human shields is also the story of those who have been included and those who have been excluded from the fold of humanity' (2020, p. 6). In doing so, the book enables us to see how designating someone as a human shield can be profoundly depoliticizing, denying them a politically qualified voice in debates about the violence inflicted upon their homes, their communities, and their bodies.

It is this that I wanted to focus on in my contribution to the symposium because something that really struck me after the attack on al-Jalaa was the complete absence of civilian voices. Several impressive legal commentaries were published in the weeks that followed, each assessing IDF claims that the attack was lawful. These commentaries invoked the usual principles and quoted the usual experts as they subjected IDF claims to critical scrutiny. Missing from these analyses were the civilians who lived and worked inside the building - the people the IDF had categorized as shields. None of the commentaries engaged with their testimony as victims, witnesses or protagonists let alone experts on the devastating consequences of military violence. Human shields were not cited in these commentaries, their concerns were not invoked, and their arguments were not picked apart-they were simply ignored. What interests me is how the dehumanization of human shields works to render their voices inaudible or unintelligible in debates about this violence and I am interested in whether the dehumanization and depoliticization of human shields can be contested. Using the attack on al-Jalaa as an example, I want to point to the many openings in Human Shields that enables us to think through and challenge the dehumanizing logic that denies human shields a politically qualified position within these legal debates, but I also want to draw attention to the book's own silences and omissions. 
Gordon and Perugini have always sought to prioritize the voices of civilians in their work on human shields, but I want to press them on some of the methodological challenges they encountered trying to excavate these voices from the archives. I want to hear their thoughts on whether there is an ethical imperative to foreground these voices in the debates about human shields and whether this will be sufficient to contest the depoliticizing logic that treats them as passive objects. For me, there is an ethical imperative, but I am also concerned that simply adding these voices will not contest the epistemic violence that denies them a politically qualified voice within the legal debate and so renders their voices inaudible.

\section{Absent voices}

The absence of civilian voices from debates about the legitimacy of the attack on al-Jalaa was not because civilians were silent. Fares Akram is a journalist with the Associated Press, which had offices inside the building. Before the IDF obliterated the building, Akram described it as the "only place in Gaza I feel somewhat safe" (Akram, 2021a). He knew the IDF had coordinates for the building and was confident that the military would not target a building occupied by international journalists. His confidence was misplaced. Shortly after the attack, Akram penned another article describing the panic he experienced when he awoke to discover the building was about to be attacked and the horror that engulfed him as he watched as it "disappeared in a shroud of dust" (Akram, 2021b). Islam as-Zaeem paints an equally vivid picture, describing how he rushed into the building to recover files from his office before it was attacked. As he descended the staircase, he recalls how he "fell down several times in the dark, shouting and crying" (quoted in Al Jazeera, 2021a). Outside the building, its owner-Jawad Mahdi-was pleading with an Israeli intelligence officer on the phone to allow people more time to remove their belongings from the tower block. When his requested was denied, Mahdi told officer that "you have destroyed our life's work" (quoted in Al Jazeera, 2021a).

The residents of al-Jalaa had a lot to say about the attack, but their voices were noticeably absent in the legal debates. Michael Schmitt (2021) published his initial assessment a few days after the building was destroyed, concluding that "based on the open-source information presently available, the strike complied with the law of armed conflict". Schmitt argues that the entire building would constitute a legitimate military objective if militants were located inside the tower block as the IDF claimed. None of those inside the building - who the IDF allege were serving as involuntary human shields-were cited in his assessment. Although he acknowledges that more evidence is needed, Schmitt argues that Hamas has a "long history of using human shielding as a tactic [so...] the IDF claim is colorable". ${ }^{1}$ Brian Cox (2021) criticized those who claimed the strike was unlawful, suggesting that they have mis-applied the definition of military objective when assessing the attack. Cox

\footnotetext{
1 Schmitt (2021) does link to a statement made by the Committee to Protect Journalists and a tweet from Amnesty Israel-Palestine.
} 
quotes several IDF statements insisting that the building was being used by a Hamas research and development unit, but he does not cite anyone living or working inside the building. Curiously, he refuses to pass judgement on the legitimacy of the attack, arguing that it is up to the military responsible for conducting the strike to decide whether it is lawful. Cox argues that his "abstention is deliberate [since...] I do not have access to all the information that is available to the IDF". Several commentators urged the IDF to reveal their evidence to avoid reputational harm, but concluded that it is the perpetrator-rather than the victim-who determines whether the attack is legitimate (Bar-On, 2021; Cohen \& Shany, 2021).

None of the legal commentaries produced in the immediate aftermath of the attack considered the perspectives of those inside the building shortly before it was attacked. None of them bothered to quote-let alone dispute-Hamas denials that militants were operating inside the building and using residents as human shields. And only one acknowledged an Associated Press statement disputing claims that Hamas were operating inside the building, but it dismisses this as ignorance, claiming that the journalists were being made to serve as human shields "without their knowledge" (Bar-On, 2021). Arguments about the legitimacy of the attack will continue to proliferate so it is important to pay close attention to who is permitted to speak on these matters and whose voices are audible. Even those commentators who commended the attack relied almost exclusively on IDF statements. Adil Ahmad Haque (2021), for example, argued that the "attack on al-Jalaa tower was so obviously illegal that one wonders how the IDF could have thought otherwise". Referring to IDF claims that its warnings were so effective that Hamas was able to remove equipment from the building, he concluded that the tower block was not a legitimate military objective at the time it was attacked. Picking apart the IDF case is an effective form of argument, but it is interesting that Haque does not quote the occupants, who have disputed the allegation that Hamas were operating inside the building in the first place (Al Jazeera, 2021b). It seems that only certain people are permitted to speak on these matters and only certain voices can be heard in these debates. The voices of those who were forced to evacuate the building and who lost homes in the attack were noticeably absent within the prevailing legal framework.

\section{Contesting the silence}

Even when commentators disagree with the position of the IDF, its statements are cited, its social media accounts are quoted, and its arguments are heard. The same cannot be said for the victims, whose voices are often missing from these legal debates. The occupants of this building were not asked to comment on allegations they were being used as human shields, they were not asked to comment on the damage done to their property, and they were not asked to comment on the effectiveness of IDF warnings. As noted in the introduction, Human Shields has been an invaluable guide to this debate, drawing attention to the ways in which human shields can be weaponized to legitimize or delegitimize specific acts of violence. Although the book was published long before al-Jalaa was destroyed, Gordon and Perugini highlight previous cases where the IDF has sought to disavow responsibility for civilian 
casualties on the grounds that Hamas were operating inside densely populated civilian areas (2020, pp. 170-175). On the one hand, they document how the discourse on human shielding works to constitute the human shield as an eminently killable subject by blurring the boundary between combatant and non-combatant (2020, pp. 177-178). On the other hand, Gordon and Perugini outline how the discourse of human shielding also works to dehumanize and depoliticize the human shield, transforming them into illicit actors in the case of voluntary shields and passive objects in the case of involuntary or proximate shields (2020, pp. 185-190).

Human Shields is a little less helpful when it comes to contesting the objectification and depoliticization of the civilian population, as the book contains its own silences and omissions. Although Gordon and Perugini document numerous instances where civilians have been categorized as human shields, few of these shields are permitted to speak. The book discusses the civilians trapped inside designated safe zones by the Sri Lankan military during the final stages of the civil war, but none of these shields are quoted in the text. Human Shields refers to the civilians forced to serve as shields by ISIS militants and explains how coalition forces used this to rationalize civilian casualties, but we do not hear from the shields themselves. And the book examines recent attacks on hospital in Yemen, which the Saudi-led coalition claims were being used by Houthi militants, but none of the medical personnel working inside these hospitals are cited. There are some notable exceptions, but Gordon and Perugini tend to engage with those who have volunteered to serve as human shields rather than those who have been categorized as such. There is a rich and detailed engagement with Agnes Maude Royden; a feminist pacifist who attempted to mobilize an army of human shields to create a buffer zone the warring parties during the invasion of Manchuria in 1931 (2020, pp. 53-59). Gordon and Perugini also engage directly with the environmental activists who have served as human shields to protect animals from attack, and the anti-war activists who travelled to Baghdad before the invasion of Iraq in 2003 (2020, pp. 96-116). Nevertheless, the voices of involuntary shields and proximate shields do not feature quite so prominently.

The purpose of the book is not to give voice to those who have been categorized as human shields, but to trace how the figure has been marshalled to (de)legitimize the violence inflicted on the battlefield. No single book can be expected to do everything, and Gordon and Perugini provide us with conceptual tools that could be used to trace how human shields have been silenced in these debates. Nevertheless, this omission seemed a little strange. I wanted to press Gordon and Perugini on whether they believe there is an imperative to include the voices of those who have served as shields and whether including these voices is sufficient to contest the dehumanizing and depoliticizing logic that rationalizes their exclusion in the first place. I am also curious what methodological problems Gordon and Perugini encountered when writing Human Shields when it came to excavating the voices of those who have served as human shields. Did they encounter these voices in the archives? Could they trace the exclusions? Were the voices of human shields ever taken seriously in debates about international humanitarian law? These issues interest me because I believe there is an ethical imperative to include these voices, but it is also something with which I have struggled in my own work. It is not clear that simply including 
these voices will be sufficient to counter the epistemic violence that discounts their experiences of this violence, that renders their voices inaudible within these debates, and that denies them a politically qualified subject position within the prevailing frames of war.

Banu Bargu (2017) touches on these in her work on human shields, highlighting both the active silencing of shields and the epistemic violence that renders their voices inaudible. Bargu is primarily concerned with voluntary human shielding, which she conceives as nonviolent resistance to armed conflict. She also expresses concern about the instrumentalization of human shields, but Bargu is particularly concerned about how their discursive deployment works to silence their voices and erase their agency. She argues that the legal debate has "little actual regard for either the knowledge or intentions of the civilian populations in question [and...] no use for their political agency" (2017, p. 300). She argues that the focus on legal manoeuvres of belligerents constricts the field of political possibility to the struggle between them, whilst reinforcing the "hegemonic construction of the civilian as a passive and voiceless, often feminized victim of violence" (2017, p. 302). In her view, the willingness of human beings to put their bodies in the line of fire challenges the assumption that civilians are inactive and ought to remain inactive during times of war. At the same time, she notes that the dominants framework of international law means that civilians will be criminalized for stepping outside the "well-scripted repertoire of political action" (2017, pp. 301-302). As Gayatri Spivak has argued in a completely different context, "even when the subaltern makes an effort to the death to speak, she is not able to be heard" (quoted in Landry \& MacLean, 1996, p. 292).

My concern is that the objectification and devaluation of the civilian population will mean that these voices will remain inaudible or unintelligible within legal debates, that the experiences of those serving as shields will be dismissed as background noise rather than politically qualified speech. So, the question I want to pose to Gordon and Perugini is whether more could be done to incorporate the voices of human shields and to ensure that these voices are heard within the prevailing legal debates. I am curious how the inclusion of these voices might disrupt the dominant frames of reference, challenging not only hegemonic conceptions of the human shield but also how the violence inflicted is categorized.

\section{Conclusion}

As I scrolled through the various tweets about the attack on al-Jalaa, I was reminded of an essay that Jacques Rancière (2009) wrote in response to the suggestion that people had been overwhelmed with images of war and desensitized to their horrors. Rejecting the argument that we have seen too much, Rancière argued that:

If horror is banalized, it is not because we see too many images of it. We do not see too many suffering bodies on the screen. But we do see too many nameless bodies, too many bodies incapable of returning the gaze that we direct at 
them, too many bodies that are an object of speech without themselves having

a chance to speak (2009, p. 96).

For him, the problem is that these debates are underpinned by a certain "distribution of the sensible" - an unspecified set of assumptions that establishes who is permitted to speak on certain issues and who is condemned to silence, that determines what can be said about certain issues and what must remain unsaid, and which delimits what can be done in response to these problems and what appears to be undoable. Rancière is also interested in those short-lived moments of political possibility when those excluded from the established order attempt to speak within its terms, temporarily disrupting the structures that conspire to keep them silent (Rancière, 2009, pp. 48-49). In these moments, he argues that it might be possible to invent new ways of being, new ways of seeing, and new forms of collective enunciation. What interests me is whether Gordon and Perugini see the same political possibilities in the voices of those serving as shields and what could be done to preserve their radical potential. Although Human Shields provides us with some insight into these opportunities, the book does not really engage with those who have been categorized as shields, so I would like to push the authors on this point.

Funding Open Access funding enabled and organized by CAUL and its Member Institutions.

Open Access This article is licensed under a Creative Commons Attribution 4.0 International License, which permits use, sharing, adaptation, distribution and reproduction in any medium or format, as long as you give appropriate credit to the original author(s) and the source, provide a link to the Creative Commons licence, and indicate if changes were made. The images or other third party material in this article are included in the article's Creative Commons licence, unless indicated otherwise in a credit line to the material. If material is not included in the article's Creative Commons licence and your intended use is not permitted by statutory regulation or exceeds the permitted use, you will need to obtain permission directly from the copyright holder. To view a copy of this licence, visit http://creativecommons.org/licen ses/by/4.0/.

\section{References}

Akram, F. (2021b). No safe place. Available online at https://www.theguardian.com/world/2021/may/16/ no-safe-place-associated-press-reporter-describes-gaza-office-attack. Accessed 25 June 2021.

Akram, F. (2021a). In Gaza, bombs drop and the conflict again hits home. Available online at https:// apnews.com/article/africa-middle-east-gaza-business-israel-palestinian-conflict-5b064a4c7ccbdd4 ac2894a73fa85a774. Accessed 25 June 2021.

Al Jazeera. (2021a). 'Give us 10 minutes': How Israel bombed a Gaza media tower. Available online at https://www.aljazeera.com/news/2021/5/15/give-us-10-minutes-how-israel-bombed-gaza-mediatower. Accessed 25 June 2021.

Al Jazeera. (2021b). Israel rolls back army chief comments on AP's 'coffee with Hamas'. Available online at https://www.aljazeera.com/news/2021/6/1/israel-rolls-back-army-chiefs-comments-of-coffee-with-hamas. Accessed 25 June 2021.

Bargu, B. (2017). Bodies against war: Voluntary human shielding as a practice of resistance. AJIL Unbound, 110, 299-304.

Bar-On, E. (2021). Israel's strike on the Gaza media building. Available online at https://www.mirya minstitute.org/commentary-blog/israels-strike-on-the-gaza-media-building-complies-with-the-lawof-armed-conflict. Accessed 25 June 2021. 
Cohen, A., \& Shany, Y. (2021). Israel, IHL and the [sic] al-Jalaa Tower. Available online at https://lieber. westpoint.edu/israel-ihl-al-jalaa-tower/. Accessed 25 June 2021.

Cox, B. L. (2021). The IDF attack on Al Jalaa Tower. Available online at https://www.justsecurity.org/ 76681/the-idf-attack-on-al-jalaa-tower-criticisms-are-correct-on-the-law-but-mistaken-in-applyingit/. Accessed 25 June 2021.

Gordon, N., \& Perugini, N. (2020). Human shields: A history of people in the line of fire. University of California Press.

Haque, A. A. (2021). The IDF's unlawful attack on Al Jalaa Tower. Available online at https://www.justs ecurity.org/76657/the-idfs-unlawful-attack-on-al-jalaa-tower/. Accessed 25 June 2021.

IDF. (2021a). IDF strikes multi-story building which contained military assets belonging to Hamas military intelligence. Available online at https:/www.idf.il/en/minisites/operation-guardian-of-thewalls/idf-strikes-multi-story-building-which-contained-military-assets-belonging-to-hamas-milit ary-intelligence/. Accessed 25 June 2021.

IDF. (2021b). Yesterday, we targeted an important base of operations for Hamas' military intel in Al Jala [sic] Tower in Gaza. Available online at https://twitter.com/IDF/status/1393797183313428482. Accessed 25 June 2021.

IDF. (2021c). Information regarding the IDF strike on the al-Jalaa building. Available online at https:// idfanc.activetrail.biz/ANC0806202101. Accessed 25 June 2021.

Landry, D., \& MacLean, G. (1996). The Spivak reader: Selected works of Gayatri Chakravorty Spivak. Routledge.

Rancière, J. (2009). The emancipated spectator (Gregory Elliott, Trans.). London: Verso.

Schmitt, M. N. (2021). Legal protection of the media in armed conflict. Available online at https://lieber. westpoint.edu/legal-protection-media-armed-conflict-gaza/. Accessed 25 June 2021.

Publisher's Note Springer Nature remains neutral with regard to jurisdictional claims in published maps and institutional affiliations. 